\title{
ANALISIS POJOK LITERASI SEKOLAH UNTUK MENINGKATKAN KREATIVITAS SISWA DALAM MEMBUAT CERPEN KELAS IV
}

\author{
Anita Putri Hardianti ${ }^{1}$, Efi Ika Febriandari ${ }^{2}$, Angga Setiawan ${ }^{3}$ \\ STKIP PGRI Trenggalek \\ Email: anitaphardianti@gmail.com
}

\begin{abstract}
Abstrak
Pojok literasi merupakan salah satu kegiatan Gerakan Literasi Sekolah yang melakukan kegitan membaca buku non pelajaran selama 15 menit sebelum jam pelajaran pertama. Pemerintah Indonesia mengembangkan Gerakan Literasi Sekolah (GLS) yang tertuang dalam Peraturan Menteri Pendidikan dan Kebudayaan No. 23 Tahun 2015. Tujuan Penelitian ini adalah untuk mengetahui pengaruh pojok literasi sekolah terhadap pembuatan cerpen siswa kelas IV. Jenis penelitian yang digunakan adalah Kualitatif mengunakan studi kasus. Instrumen yang digunakan dalam penelitian ini adalah lembar observasi mengenai keadaan kelas IV. Subjek penelitian adalah siswa kelas IV. Wawancara dengan wali kelas IV dan 23 siswa kelas IV. Dokumentasi tentang pembuatan cerpen dan pojok literasi. Hasil penelitian menunjukan dengan adanya pojok literasi siswa menjadi lebih aktif dan kreatif, karena hampir setiap hari mereka dilatih untuk membaca buku cerita. Membuat cerpen dari buku bacaan yang ada di pojok literasi yang membuat siswa lebih kreatif mengarang cerita, sehingga hasil dari mereka rajin membaca di pojok literasi adalah siswa dapa membuat cerpen dengan baik dan kreatif.
\end{abstract}

Kata Kunci: Gerakan Literasi, Pojok Baca, Cerpen.

\begin{abstract}
Cornering is one of the activities of the school literacy movement that includes literacy reading non-lesson books for 15 minutes before the first period. The Indonesian government has developed a school literacy movement (GLS) embodied in the 2015 ministry of education and culture no.23. The purpose of this study is to know the impact of school literacy on creating grade IV. The kind of research used is qualitative using case studies. The instrument used in this study is an observation sheet regarding the condition of class IV. The research subject is a grade IV grade. Interview with homeroom iv and 23 class iv students. a documentary on pen making and corner literacy. Research suggests that one end of the students' literacy has become more active and creative, since they are almost daily trained to read storybooks. Creating a subtext from a textbook in the corner of the literacy that makes students more creative storytelling, so the result of their diligent reading in the corner of the literature is that the dapa student makes a good and creative storytelling.
\end{abstract}

Keywords: literacy movements, corner reading, storytelling.

\section{Pendahuluan}

Pojok Literasi atau pojok baca merupakan suatu bentuk kegiatan yang sejenis dengan perpustakaan namun terdapat di dalam kelas. Sejalan dengan pernyataan tersebut, pojok baca merupakan sebuah tempat di dalam kelas yang dilengkapi dengan koleksi buku dan ditata secara menarik untuk meningkatkan minat baca. Kemendikbud (2016:9). Kegiatan Gerakan Literasi Sekolah juga sangat mempengaruhi proses belajar mengajar siswa, minat baca siswa juga sangat dipengaruhi dari 
seringnya siswa membaca buku. Pembinaan membaca kepada Gerakan Literasi Sekolah merupakan anak melalui pojok literasi merupakan gerakan literasi yang akivitasnya banyak langkah awal sekaligus cara efektif untuk dilakukan di sekolah dengan melibatkan menumbuhkan minat baca kepada anak warga sekolah seprti siswa, guru, kepala karena dimasa anak-anak merupakan sekolah, tenaga kependidikan, masa yang tepat untuk menanamkan pengawas sekolah, komite sekolah, sebuah kebiasaan yang nantinya orang tua/ wali murid, akademisi, penerbit, media massa, masyarakat. Kemendikbud (2016:16)

Salah satu dimensi adalah literasi baca dan tulis. Literasi baca dan tulis adalah pengetahuan dan kecakapan untuk membaca, menulis, mencari, menelusuri, mengolah, dan memahami informasi. Kemendikbud (2016:6-7). Salah satu bentuk literasi tulis adalah dengan membuat cerita pendek. Dari situ siswa dituntut untuk merangkai secerita sebuah cerita yang tersusun dengan memasukan unsur-unsurcerpen didalamnya. Pada penelitian ini peneliti menggali informasi mengenai bagaimana bentuk wujud kegiatan pojok literasi sekolah di kelas IV SDN 2 Gandusari, bagaimana kreativitas siswa dalam membuat cerpen, dan bagaimana peranan Pojok Literasi Sekolah Untuk Meningkatkan Kreativitas Siswa Dalam Pembuatan Cerpen Kelas IV di SDN 2 Gandusari. Metode yang peneliti gunakan adalah wawancara,observasi dan juga dokumentasi. kebiasaan ini akan terbawa hingga dewasa. "Dengan kata lain, apabila sejak kecil anak terbiasa membaca, maka kebiasaan membaca akan terbawa hingga dewasa. (Aswat dan Maya 2020:74) Pelaksanaan program gerakan literasi sekolah menurut Suragangga dalam Batubara dan Ariani, (2018: 15) mengacu pada prinsip sebagai berikut: 1. Sesuai dengan tahapan perkembangan peserta didik.

2. Dilaksanakan menggunakan berbagai ragam teks.

3. Dilaksanakan secara terintegrasi dan holistik di semua area kurikulum.

4. Dilakukan secara berkelanjutan.

5. Melibatkan kecakapan berkomunikasi lisan.

6. Mempertimbangkan keberagaman.

Berdasarkan wawancara dan observasi yang peneliti lakukan dengan guru kelas dapat diuraikan bahwa jumlah siswa kelas IV di SDN 2 Gandusari yaitu 23 siswa. Menurut wali kelas IV siswa kelas IV mengalami kesulitan untuk membuat cerpen sebelum adanya pojok 
baca karena minat baca dan tulis siswa kurang. Kesulitan siswa dialami karena siswa belum terbiasa membaca buku dan melakukan kegiatan menulis hanya jika ada tugas saja. Menurut Kharizmi Muhammad (2019:96) tingkat literasi siswa di seluruh dunia dapat diketahui dari tiga studi internasional yang dipercaya sebagai instrumen untuk menguji kompetisi global yaitu PIRLS (Progress in International Reading Literacy Study), PISA (Programme for International Student Assesment), dan TIMSS ( Trend in Internasional Mathematics an Science Study). Berdasarkan kajian terhadap ketrampilan literasi anak-anak di seluruh dunia yang dilaksanakan oleh PIRLS (Progress in International Reading Literacy Study) diperoleh data bahwa siswa Indonesia berada pada tingkat terendah di kawasan Asia. Kharizmi Muhammad (2019:97)

Melihat fenomena seperti ini wali kelas IV membuat inisiatif untuk membuat pojok literasi di dalam kelas. Selain untuk menunjang kegiatan Gerakan Literasi Sekolah pembuatan pojok literasi juga bertujuan untuk melatih anak agar terbiasa membaca dan menulis setiap harinya. Pembuatan pojok literasi dilakukan secara bersama- sama dengan siswa agar siswa juga mengathui proses pembuatnnya.

Peneliti melakukan penelitian ini karena melihat kebiasaan membaca dan menulis di kelasIV yang kurang. Hal tersebut berdampak pada penerimaan siswa terhadap eljaran yang diberikan guru. Terlebih pada saat membuat cerpen siswa mengalami kesulitan karena kurangnya minat membaca dan menulis siswa. Oleh karena itu peneliti mengadakan penelitian yang berjudul " Analisis Pojok Literasi Untuk Meningkatkan Kreativitas Siswa Kelas IV di SDN 2 Gandusari”.

\section{Metode}

Penelitian Analisis Pojok Literasi Untuk Meningkatkan Kreativitas Siswa Kelas IV di SDN 2 Gandusari menggunakan jenis penelitian studi kasus dan sifat penelitiannya kualitatif naturalistik yakni menggunakan cara dengan mengamati dan pengumpulan data yang dilakukan dalam latar alamiah, menurut Arikunto (2015:185) "penelitian kasus adalah suatu penelitian yang dlakukan secara intensif terinci dan mendalam terhadap suatu organisasi, lemabaga dan gejala tertentu artinya tanpa memanipulasi subjek yang diteliti (sebagaimana adanya) di lapangan secara lebih mendalam mengenai 
Analisis Pojok Literasi Untuk yang akan digunakan untuk penelitian, Meningkatkan Kreativitas Siswa Kelas IV menentukan sampel penelitian, di SDN 2 Gandusari Prosedur penelitian menyusun proposal penelitian dengan yang dilakukan peneliti ada beberapa arahan dan bimbingan dari dosen tahap yang harus dilakukan. Dalam pembimbing, menyusun instrumen penelitian ini juga mengunakan metode penelitian. Tahap pekerjaan lapangan kualitatif menurut Sugiyono (2015:276) kegiatan yang dilakukan peneliti adalah "penelitian kualitatif dapat meningkatkan melakukan penelitian pengumpulan data transferabilitas dengan melakukan suatu instrumen yang berupa observasi, pekerjaan mendiskripsikan konteks wawancara, dokumentasi. Tahap analisis penelitian dan asumsi-asumsi yang data yang digunakan yaitu seluruh data menjadi sentral pada penelitian tersebut. hasil penelitian yang telah diperoleh dan Oleh karena itu, agar orang lain mampu telah dianalisis oleh peneliti disusun memahami hasil penelitian kualitatif secara sistematis pada laporan hasil sehingga ada kemungkinan untuk penelitiaan.

menerapkan hasil penelitian tersebut,

Metode pengumpulan data yang maka seorang peneliti dalam membuat digunakan penelitian ini adalah laporannya harus memberikan uraian instrumen observasi., instrumen secara rinci, jelas, sistematis serta dapat wawancara untuk siswa dan guru, dan dipercaya. Moleong (2017:127) dokumentasi. Subjek penelitian ini mengemukakan bahwa "ada tiga tahap adalah siswa kelas IV yang berjumlah penelitian yaitu tahap pra lapangan, 23 siswa. Waktu penelitian dilaksanakan tahap pekerjaan lapangan dan tahap tiga tahap, pada tahap pertama tanggal analisis data." Pada tahap pra lapangan 12-18 Maret 2020 ketika peneliti ini kegiatan yang dilakukan peneliti melakukan observasi dengan adalah mengajukan judul penelitian, mendatangi SDN 2 Gandusari, yakni meminta surat permohonan izin mengamati kondisi sekolah SDN 2 penelitian dari STKIP PGRI Trenggalek, Gandusari dimana peneliti mendatangi mengajukan surat permohonan izin sekolah bertemu dengan kepala penelitian kepada Sekolah Dasar yang sekolah. Meminta izin untuk meliihat dituju yaitu SDN 2 Gandusari untuk kondisi sekolah, ruangan kelas IV dan mengadakan penelitian di Sekolahan pojok literasi yang ada di kelas pada tersebut, observasi awal ke Sekolah tahap kedua tanggal 09 Juni 2020 
peneliti memastikan kembali waktu yang tepat untuk melakukan observasi dan wawancara dengan siswa kelas IV dan wali kelas IV mengenai pengaruh pojok literasi terhadap pembuatan cerpen siswa, pertama-tama peneliti mewawancarai wali kelas IV dan mengajukan 16 pertanyaan yang djawab oleh wali kelas IV secara sadar dan apa adanya. Lalu dilanjutkan dengan mewawancarai 12 siswa kelas IV yang menjawab 12 prtanyaan yang sudah disiapkan peneliti, dan pada tahap ketiga pada tanggal 10 Juni 2020 melakukan data dokumentasi dengan menemui operator SDN 2 Gandusari meminta arsip data guru, ruangan kelas, prestasi sekolah, visi, misi, tujuan sekolah tak lupa memfoto kondisi SDN 2 Gandusari.

Pada penelitian ini menggunakan teknik analisis data yang digunakan penelitian ini adalah Data Reduction (Reduksi Data), Data Display (Penyajian Data), Verifikasi Data (Conclusions drowing/verifiying). Untuk pengecekan keabsahan data yang telah diperoleh peneliti yaitu meliputi Uji Credibility (kredibilitas), Transferability (Validitas eksternal), Dependability (Reliabilitas), dan Confirmability (Obyektivitas).

\section{Hasil dan Pembahasan}

Gerakan Literasi Sekolah (GLS) telah digulirkan mulai Maret 2016 oleh Direktorat Jendera Pendidikan Dasar dan Menengah Kemendikbud dengan melakukan sosialisasi dan koordinasi ke semua Dinas Pendidikan Provinsi dan/atau Dinas Pendidikan Kota/Kabupaten. Kegiatan pojok literasi sekolah di kelas IV SDN 2 Gandusari yaitu dengan melakukan literasi membaca selama 15 menit sebelum jam pembelajaran, kegiatan membaca bersama dan juga menyusun buku sesuai tempatnya. Buku-buku yang terdapat di pojok literasi juga beragam mulai dari bukuelajaran hingga bukubacaan seperti dongeng, kisahkisah pahlawan, ara nabi dan lain-lain.

Selain itu kreativitas siswa dalam membuat cerpen juga diamati oleh peneliti. Perlu diketahui sebelum adanya pojok literasi ini kreativitas siswa dalam membuat cerpen belum begitu terasah, karena siswa di SDN 2 Gandusari sangat aktif dalam ketrampilan perunjukan seni, sehingga Kepala Sekolah dan Guru membentuk pojok literasi disetiap kelas agar menunjang pemahaman siswa tentang membaca dan menulis.

Lalu dengan adanya pojok literasi tersebut siswa mulai menunjukan peningkatan dalam membuat cerpen. Karena guru dengan tertib mengajak 
siswa untuk membiasakan membaca buku lalu meringkas apa yang telah mereka baca. Secara perlahan guru mengajarkan apa saja unsur yang terdapat pada cerpen, sehingga siswa dengan mudah untuk membuat cepen jika sudah mengetahui unsurnya. Walaupun siswa masih kesulitan dalam merangkai kata-kata namun mereka sudah cukup sering membuat cerpen. Dan yang sebelumnya siswa belum begitu mengenal cerpen sekarang siswa sudah terbiasa membuat cerpen.

\section{Kesimpulan}

Berdasarkan hasil penelitian dan pembahasan yang telah diuraikan mengenai Bagaimana bentuk wujud kegiatan pojok literasi sekolah di kelas IV SDN 2 Gandusari, bagaimana kreativitas siswa dalam membuat cerpen, bagaimana peranan Pojok Literasi Sekolah Untuk Meningkatkan Kreativitas Siswa Dalam Pembuatan Cerpen Kelas IV di SDN 2 Gandusari ,maka dapat ditarik kesimpulan bahwa Gerakan Literasi Sekolah merupakan program yang ditetapkan oleh pemerintah yang bertujuan untuk meningkatkan minat baca siswa di Indonesia. Program ini sudah diterapkan di SDN 2 Gandusari yang membiasaka siswanya untuk membca buku di perpustakaan.
Salah satu program yang dibuat SDN 2 Gandusari untuk menunjang Gerakan Lierasi Sekolah yaitu membuat pojok literasi di setiap kelas. Gunanya agar siswa lebih aktif dan tertib membaca buku. Di pojok literasi tersebut juga terdapat buku bacaan yang disediakan selain buku pelajaran.

Pojok Literasi juga berguna bagi siswa untuk meningkakan kreativitas dalam membuat cerpen. Masih banyak siswa yang hanya membaca saja namun idak tau arti apa yang dibaca. Sehingga sisi lain dari peran pojok literasi di kelas selain untuk tempat membaca buku adalah sarana mereka berkerativitas membuat cerpen atau juga bisa dikatan sebagai output dari hasil membaca buku cerita yang ada di pojok literasi siswa dapat membuat cerpen berdasarkan dengan buku yang dibaca.

Berdasarkan simpulan di atas, penulis ingin mengungkapkan saransaran bagi guru SDN 2 Gandusari agar selalu memotivasi siswa untuk giat membaca, karena dengan membaca akan membuka pikiran siswa dan membuat mereka lebih tekun. Belajar lebih muda paham. Dengan membaca mereka juga bisa mengikuti perlombaan seperti yang pernah siswa SDN 2 Gandusari ikuti yaitu Juara 2 Baca Puisi Tingkat Kecamatan 2015, Juara 1 
Lomba Pidato Bahasa Inggris tingkat melakukan penelitian lebih mendalam kecamatan tahun 2016. Oleh karena itu lagi terkait Analisis Pojok Baca, Cerpen dengan memanfaatkan pojok literasi di atau penelitian yang sejenis. Sehingga kelas dengan opimal akan menghasilkan mampu mengembangkan apa yang telah anak-anak yang gemar membaca. Bagi di temukan oleh peneliti selanjutnya atau peneliti selanjutnya, hendaknya dapat bahkan jauh menemukan hal baru lagi.

\section{DAFTAR RUJUKAN}

Kementrian Pendidikan dan Kebudayaan Republik Indonesia. (2016). Panduan Gerakan Lierasi Sekolah. Jakarta: Kemendikbud.

Kemendikbud. (2015) . Peraturan Menteri Pendidikan dan Kebudayaan nomor 23 tahun 2015 tentang Penumbuhan Budi Pekerti. Jakarta: Kemendikbud.

Kharizmi Muhammad. 2019. Kesulitan Siswa Dalam Meningkatkan Kemampuan Literasi. Jurnal Pendidikan Almuslimin. Volume VII Nomor 2. (Agustus 2019) hlm 96-97 diakses 9 Juli 2020

https://scholar.google.com/scholar?hl=id\&as_sdt=0\%2C5\&q=jurnal+pendidikan+ almuslimin\&btnG=\#d=gs_qabs\&u=\%23p\%3DTtmtucJYCNIJ

Moleong, Lexy. 2017. Metodologi Penelitian Kualitatif.. Bandung: PT Remaja Rosdakarya

Aswat dan Nurmaya. 2020. Analisis Gerakan Literasi Pojok Baca Kelas Terhadap Eksistensi Daya Baca Anak Di Sekolah Dasar. Jurnal Kependidikan.Volume 4 Nomor 2.

http://pgsd.umk.ac.id/files/prosiding/2017/3\%20Mulyo\%20Teguh.pdf diakses pada tanggal 12 Februari 2020.

Batubara dan Ariani. 2018. Implementasi Program Gerakan Literasi Sekolah Di Sekolah Dasar Negeri Gugus Sungai Miai Banjarmasin. Jurnal Kependidikan.(Online).Volume 4 Nomor 1.

http://150.107.142.250/index.php/jpsd/article/view/2965 diakses pada tanggal 12 Februari 2020.

Arikunto.2015.Prosedur Penelitian.Jakarta .Penerbit PT RINEKA CIPTA

Sugiyono. (2017). Metode Penelitian Pendidikan.Bandung: Alfabeta. 